\title{
Hexokinase activity is affected in mutants of Kluyveromyces lactis resistant to glucose repression
}

\author{
Paola Goffrini, Antonella Ficarelli and Iliana Ferrero \\ Author for correspondence: Paola Goffrini. Tel: +39521 905602. Fax: + 39521905604.
}

Institute of Genetics, University of Parma, Viale delle Scienze, 43100 Parma, Italy

\begin{abstract}
The effect of glucose on a number of mitochondrial and cytoplasmic enzymes involved in carbon metabolism (L-lactate:ferricytochrome-c 2-oxidoreductase, malate dehydrogenase, $\beta$-galactosidase, invertase, maltase and NADglutamate dehydrogenase) has been analysed in two different strains of Kluyveromyces lactis (PM4-4B and JA6 strains). All the above mentioned enzymes were catabolite-repressible in a strain-dependent way. From this study differences in the regulation of some enzymes have been observed between $\boldsymbol{K}$. lactis and Saccharomyces cerevisiae. To identify genes involved in glucose metabolism that may also control carbon catabolite repression, 2-deoxyglucose-resistant mutants (Dgr ${ }^{+}$) of $K$. lactis that were unable to grow on glucose in the presence of antimycin $A\left(\mathrm{Rag}^{-}\right)$were selected. In this way we identified four classes of mutants. Two of them define genes previously identified: RAG1 and RAG5, encoding the low affinity glucose transport system and hexokinase, respectively. The two remaining classes of mutants define two new genes, DGR148 and DGR239, that control the level of hexokinase, indicating that in $K$. lactis this enzyme is positively regulated by at least two genes. All the mutants devoid of hexokinase showed relief from carbon catabolite repression of several enzymes.
\end{abstract}

Keywords: Kluyveromyces lactis, glucose repression, hexokinase, regulatory mutants

\section{INTRODUCTION}

In the yeast Saccharomyces cerevisiae, as in other microorganisms (Magasanik, 1961), the level of activity of several enzymes is subjected to repression by glucose or other rapidly fermentable carbon sources. This phenomenon, called catabolite repression, is a complex regulatory mechanism that intervenes in the control of the expression of several genes involved both in fermentative (Polakis \& Bartley, 1965; Gorts, 1967) and oxidative (Slonimski, 1953; Polakis $e t$ al., 1965) metabolism in yeast. In order to identify the different elements controlling this regulatory system, many carbon catabolite repression mutants have been isolated and characterized (reviewed by Gancedo \& Gancedo, 1986). They suggested that carbon catabolite repression is under the control of interacting genes, and Gancedo (1992) has developed a model to explain the interactions.

Abbreviations: EMS, ethylmethanesulfonate; L-LCR, L-lactate: ferricytochrome-c 2-oxidoreductase (EC 1.1.2.3); $\mathrm{MDH}$, malate dehydrogenase (EC 1.1.1.37); NAD-GDH, NAD-dependent glutamate dehydrogenase (EC 1.4.1.3).
In $S$. cerevisiae, one of the glucose-repressed functions is respiration. Thus, carbon metabolism is either oxidative or fermentative. Contrary to what is observed in $S$. cerevisiae, glucose catabolite repression of respiration does not occur in the obligately aerobic Kluyveromyces lactis (De Deken, 1966a, b; Ferrero et al., 1978). Therefore, fermentative and oxidative utilization of carbon sources co-exist in $K$. lactis. However, carbon catabolite repression of some cytoplasmic enzymes has been described in $K$. lactis (Ferrero et al., 1978; Dickson \& Markin, 1980). In particular, much is known about glucose repression of lactose/galactose metabolism mediated by the LAC9 gene (Wray et al., 1987; Breunig, 1989; Zachariae et al., 1993), the K. lactis homologue of the $S$. cerevisiae regulatory gene GAL4 (Salmeron \& Johnston, 1986; Wray et al., 1987; Breunig \& Kuger, 1987). Recently it was found that the two mitochondrial enzymes $L^{-}$and D-lactate:ferricytochrome-c 2-oxidoreductase are repressible by glucose (Lodi et al., 1994). However, in K. lactis mutations affecting the general response to carbon catabolite repression have not hitherto been described.

For this reason we first identified enzymes responding to glucose repression in $K$. lactis. We then isolated mutants 
in which the repressing effects of glucose were pleiotropically relieved in order to identify regulatory genes involved in the control of glucose repression. These mutants defined four complementation groups, three of which are affected in hexokinase activity, thus demonstrating that hexokinase has a central role in the regulation of glucose repression in $K$. lactis.

\section{METHODS}

Strains and general genetic methods. Strains used in this study are listed in Table 1 . Genetic procedures for crossing and sporulation have been previously described (Wésolowski et al., 1982; Goffrini et al., 1989). Rich medium (YP) contained $5 \mathrm{~g}$ Difco Bacto yeast extract $\mathrm{l}^{-1}$ and $10 \mathrm{~g}$ Difco Bacto peptone $\mathrm{l}^{-1}$. The synthetic minimal medium contained $0 \cdot 7 \mathrm{~g}$ Difco yeast nitrogen base (without amino acids) $1^{-1}$ supplemented with amino acids and bases, as required.

The different carbon sources utilized were added at $2 \%(w / v)$. 2-Deoxy-D-glucose (Fluka) was added at the concentration indicated in Results, according to the minimal inhibitory concentration determined previously (data not shown). Antimycin A (Sigma) was used at a final concentration of $5 \mu \mathrm{M}$. For mating and sporulation the medium was $50 \mathrm{~g}$ Difco Bacto maltextract $1^{-1}$. Media were solidified with $20 \mathrm{~g}$ Difco Bacto agar $\mathrm{l}^{-1}$.

Isolation of mutants. Mutants were isolated using ethylmethanesulfonate (EMS) as a mutagen. The JA6 strain was grown to stationary phase, collected, washed with $0.1 \mathrm{M}$ potassium phosphate buffer, $\mathrm{pH} 8$, and resuspended in the same buffer at $1 \times 10^{8}$ cells $\mathrm{ml}^{-1}$. Cell suspension $(3 \mathrm{ml})$ was divided into three portions of $1 \mathrm{ml}$ and treated with EMS $\left(20 \mu \mathrm{l} \mathrm{ml} \mathrm{l}^{-1}\right.$, $10 \mu \mathrm{ml}^{-1}, 5 \mu \mathrm{ml}^{-1}$ ) for $45 \mathrm{~min}$. The cells were then washed three times with water, suspended in complete medium and incubated for $90 \mathrm{~min}$ at $28{ }^{\circ} \mathrm{C}$. The cells were harvested, washed with water and plated to determine cell survival. Those samples of EMS-treated cells which exhibited survival rates from $10 \%$ to $20 \%$ were used to screen for mutants. To select for nonrepressible mutants, cells were plated onto minimal medium containing $20 \mathrm{~g}$ raffinose $\mathrm{1}^{-1}$ and $5 \mathrm{~g}$ 2-deoxyglucose $\mathrm{l}^{-1}$ and maintained at $28{ }^{\circ} \mathrm{C}$. After a week, approximately 1500 colonies appeared.

Dominance tests and complementation analysis. To test for dominance, each of the mutants was crossed to the wild-type strain PG9-11D. For complementation analysis with rag1, mutants were crossed with the PG13-20C strain harbouring a null rag1 allele. To test the identified mutations for allelism, segregants (PG139-7B, PG148-3A, PG151-7C and PG239-5B) derived from back-crosses of the mutants with the wild-type strain were crossed to the original mutants. In most cases diploids were isolated by prototrophic selection.

For allelism with previously identified mutations conferring the same phenotype (from rag2 to rag13 and $p f k 2$ ) heterozygous diploids were constructed by crossing either the original mutant or a segregant to each of the previously identified mutants. When the selection against both haploid parents was not possible, diploids were identified by testing for the ability of single colony derived from the cross to sporulate. Complementation tests were performed by replica-plating of the diploids onto antimycin-A-containing medium and the Rag phenotype was scored after $48 \mathrm{~h}$.

\section{Table 1. List of $K$. lactis strains}

\begin{tabular}{|c|c|c|}
\hline Strain & Genotype & Source \\
\hline HK5-4D & $\begin{array}{l}\text { a ade bis3-35 leu2-137 ura3-12 } \\
\text { pfle2::UR } A 3\end{array}$ & Obtained from Dr J. Heinisch \\
\hline JA6 & $\alpha$ ade 1 ade $2 \operatorname{trp}-11$ ura $A$ & Obtained from Dr K. D. Breunig \\
\hline JA6/138 & $\alpha$ ade 1 ade 2 trp1-11 ura $A$ dgr 138 & This study \\
\hline JA6/139 & $\alpha$ ade 1 ade $2 \operatorname{trp} 1-11$ ura $A$ dgr 139 & This study \\
\hline $\mathrm{JA} 6 / 148$ & $\alpha$ ade 1 ade 2 trp1-11 ura $A$ dgr148 & This study \\
\hline $\mathrm{JA} 6 / 151$ & $\alpha$ ade 1 ade $2 \operatorname{trp} 1-11$ ura $A$ dgr 151 & This study \\
\hline $\mathrm{JA} 6 / 239$ & $\alpha$ ade 1 ade $2 \operatorname{trp} 1-11$ ura $A$ dgr239 & This study \\
\hline MW109-8C/FA39 & $\alpha \operatorname{lys} A 1-1 \operatorname{trp} A 1 \mathrm{rag} 9$ & Obtained from Dr M. Wésolowski-Louvel \\
\hline MW109-8C/FA42 & $\alpha$ lys $A 1-1$ rag8 & Obtained from Dr M. Wésolowski-Louvel \\
\hline MW125-21A & $\alpha$ ura $A$ rag4 & Obtained from Dr M. Wésolowski-Louvel \\
\hline MW161-3B & $\alpha \operatorname{lys} A 1-1$ rag 10 & Obtained from Dr M. Wésolowski-Louvel \\
\hline MW188-1C & a $\operatorname{lys} A 1-1 \operatorname{trp} A 1 \operatorname{rag} 12$ & Obtained from Dr M. Wésolowski-Louvel \\
\hline PG9-11D & a $\operatorname{trp} 1 \operatorname{met} A 1$ ura $A$ & Parma collection \\
\hline PG13-20C & a $\operatorname{trp} 1$ met $A 1$ ura $A$ rag1::UR $A 3$ & Parma collection \\
\hline PG139-7B & a met $A 1 \operatorname{trp} 1$ ura $A$ dgr139 & This study \\
\hline PG148-3A & a met $A 1 \operatorname{trp} 1$ ura $A$ dgr 148 & This study \\
\hline PG151-7C & a met $A 1 \operatorname{trp} 1$ ura $A \operatorname{dgr} 151$ & This study \\
\hline PG239-5B & a met $A 1 \operatorname{trp} 1$ ura $A$ dgr 239 & This study \\
\hline PM4-4B & $\alpha$ ade 1 ade 2 ura $A$ & Parma collection \\
\hline PM4-4B/RAG2 & $\alpha$ ade 1 ade 2 ura $A$ rag2:: $U R A 3$ & Parma collection \\
\hline PM6-7A/VV10 & a ade 2 ura $A$ rag11 & Obtained from Dr M. Wésolowski-Louvel \\
\hline PM6-7A/VV13 & $a$ ade 1 ade 2 ura $A$ rag 3 & Obtained from Dr M. Wésolowski-Louvel \\
\hline PM6-7A/VV18 & a ade 2 ura $A$ rag7 & Obtained from Dr M. Wésolowski-Louvel \\
\hline PM6-7A/VV36 & a ade 2 ura $A$ rag13 & Obtained from Dr M. Wésolowski-Louvel \\
\hline PM6-7A/VV41 & a ade 2 ura $A$ rag 5 & Obtained from Dr M. Wésolowski-Louvel \\
\hline
\end{tabular}


Preparation of cell-free extract and enzyme assays. Cells grown at a density of approximately $5 \times 10^{7}$ cells $\mathrm{ml}^{-1}$ were harvested by centrifugation and washed once with distilled water. The cell pellet was resuspended in extraction buffer $(0 \cdot 1 \mathrm{M}$ Tris/ $\mathrm{HCl}, \mathrm{pH} 8 \cdot 5,1 \mathrm{mM}$ phenylmethylsulfonyl fluoride) and the cells were disrupted by vortexing at $4{ }^{\circ} \mathrm{C}$ in the presence of an equal volume of glass beads $(0.5 \mathrm{~mm}$ diameter $)$. The suspension was then centrifuged at $5000 \mathrm{~g}$ for $5 \mathrm{~min}$ at $4{ }^{\circ} \mathrm{C}$. The pellet was discarded and the supernatant utilized for measuring the enzyme activity. The Lowry method was used for protein quantification with bovine serum albumin as standard.

$\beta$-Galactosidase (EC 3 2.1.23) activity was assayed as described by Cohn \& Monod (1951). L-Lactate:ferricytochrome-c 2oxidoreductase (L-LCR) (EC 1.1.2.3) was assayed according to Lodi et al. (1994). Total malate dehydrogenase (MDH) (EC 1.1.1.37) was assayed according to Polakis \& Bartley (1965). NAD-dependent glutamate dehydrogenase (NAD-GDH) (EC 1.4.1.3) was assayed as described by Grisolia et al. (1964). Total $\alpha$-glucosidase (maltase, EC 3.2.1.20 and isomaltase, EC 3.2 .1 .10 ) activity was tested with $p$-nitrophenyl-O-D-glucopyranoside as a substrate as described by Zimmermann $e t$ al. (1977); hexokinase (EC 2.7.1.1) was assayed with glucose as substrate, as described by Clifton et al. (1978); invertase (EC 3.2.1.26) was assayed according to Goldstein \& Lampen (1975) and to Celenza \& Carlson (1984).

\section{RESULTS}

\section{$K$. lactis enzymes repressed by glucose}

In order to define the spectrum of enzyme activities sensitive to glucose catabolite repression in $K$. lactis, the cytoplasmic enzymes invertase, maltase, NAD-GDH and $\beta$-galactosidase, the total MDH (cytoplasmic and mitochondrial) and the mitochondrial enzyme L-LCR were analysed in cultures grown in the presence or in the absence of glucose. The effect of glucose on the levels of

Table 2. Effect of glucose on the level of maltase, invertase, NAD-GDH, $\beta$-galactosidase, MDH and L-LCR in PM4-4B and JA6 strains of $K$. lactis

Strain genotypes are listed in Table 1. Cultures were grown in YP medium supplemented with $2 \%(\mathrm{w} / \mathrm{v})$ lactate with or without the addition of $2 \%(\mathrm{w} / \mathrm{v})$ glucose. Enzyme activities were measured as described in Methods. Enzyme units are expressed as nmol substrate $\mathrm{min}^{-1}$ (mg protein $)^{-1}$. All values are means of three independent experiments. In no case was the variation higher than $15 \%$.

\begin{tabular}{|c|c|c|c|c|}
\hline \multirow[t]{3}{*}{ Enzyme } & \multicolumn{4}{|c|}{ Strain } \\
\hline & \multicolumn{2}{|c|}{ PM4-4B } & \multicolumn{2}{|c|}{ JA6 } \\
\hline & Lactate & $\begin{array}{c}\text { Lactate } \\
+ \text { glucose }\end{array}$ & Lactate & $\begin{array}{c}\text { Lactate } \\
+ \text { glucose }\end{array}$ \\
\hline Maltase & $<3$ & $<3$ & 109 & $<3$ \\
\hline Invertase & 83 & 54 & 97 & $<3$ \\
\hline NAD-GDH & 380 & 150 & 2090 & 550 \\
\hline$\beta$-Galactosidase & 411 & 200 & 64 & 22 \\
\hline $\mathrm{MDH}$ & 2820 & 1715 & 1475 & 323 \\
\hline L-LCR & 490 & 89 & 98 & 17 \\
\hline
\end{tabular}

Table 3. Effect of glucose on the level of maltase, invertase and $\beta$-galactosidase in PM4-4B and JA6 strains of $K$. lactis grown in the presence of the specific substrates

Strain genotypes are listed in Table 1. Cultures were grown in YP medium supplemented with $2 \%(\mathrm{w} / \mathrm{v})$ maltose, raffinose or galactose for the determination of maltase, invertase and of $\beta$ galactosidase, respectively, with or without the addition of $2 \%$ $(\mathrm{w} / \mathrm{v})$ glucose. Enzyme activities were measured as described in Methods. Enzyme units are expressed as nmol substrate min $^{-1}$ $(\mathrm{mg} \text { protein })^{-1}$. All values are means of three independent experiments. In no case was the variation higher than $15 \%$.

\begin{tabular}{|c|c|c|c|c|}
\hline \multirow[t]{3}{*}{ Enzyme } & \multicolumn{4}{|c|}{ Strain } \\
\hline & \multicolumn{2}{|c|}{ PM4-4B } & \multicolumn{2}{|c|}{ JA6 } \\
\hline & $\begin{array}{c}\text { No } \\
\text { glucose }\end{array}$ & Glucose & $\begin{array}{c}\text { No } \\
\text { glucose }\end{array}$ & Glucose \\
\hline Maltase & 80 & 5 & 55 & $<3$ \\
\hline Invertase & 146 & 76 & 189 & $<3$ \\
\hline$\beta$-Galactosidase & 2070 & 1790 & 909 & 176 \\
\hline
\end{tabular}

these enzymes was carried out in two different strains: PM4-4B and JA6. Cultures of these strains were prepared on media containing either lactate as a 'nonrepressing' carbon source or lactate plus glucose. The data obtained are reported in Table 2 . All the enzyme activities measured were sensitive to catabolite repression, though to different extents. The JA6 strain was more sensitive to glucose than the PM4-4B strain for all the enzymes tested, except for maltase, which in PM4-4B was undetectable in the presence of lactate. In addition, a strain-dependent level of the enzymes was observed in cultures grown in the absence of glucose (nonrepressed level).

We then tested maltase, invertase and $\beta$-galactosidase in cells grown in the presence of the specific substrate and possible inducers: maltose, raffinose and galactose, respectively. The analysis of the results reported in Table 3 indicates that, in both strains analysed, there was a high degree of induction of $\beta$-galactosidase and a twofold induction only for invertase. For maltase the results were very different depending on the strain used: in PM4-4B maltase was detectable only after growth on maltose while in JA6 maltose had a small repressing effect. Based on these results we decided to use the JA6 strain to develop the study of catabolite repression.

\section{Isolation of nonrepressible mutants}

The use of 2-deoxyglucose as a nonmetabolizable glucose analogue that acts also as a gratuitous repressor is one of the most general procedures utilized to obtain nonrepressible mutants (Zimmermann \& Scheel, 1977). For this reason the JA6 haploid strain was mutagenized with EMS and then plated onto medium containing $5 \mathrm{~g}$ 2-deoxyglucose $\mathrm{l}^{-1}$ and $20 \mathrm{~g}$ raffinose $\mathrm{l}^{-1}$. The frequency of appearance of resistant colonies was $4 \times 10^{-4}$. Among 
Table 4. Effect of glucose on the level of maltase, invertase, NAD-GDH, $\beta$-galactosidase and $\mathrm{MDH}$ in dgr139, dgr148, dgr151 and dgr239 mutants of $\mathrm{K}$. lactis

Strain genotypes are listed in Table 1. Cultures were grown in YP medium supplemented with $2 \%$ $(\mathrm{w} / \mathrm{v})$ raffinose or galactose for the determination of invertase and $\beta$-galactosidase, respectively, or $2 \%$ $(w / v)$ lactate for the determination of maltase, $\mathrm{MDH}$ and NAD-GDH, with or without the addition of $2 \%(\mathrm{w} / \mathrm{v})$ glucose. Enzyme activities were measured as described in Methods. Enzyme units are expressed as nmol substrate $\mathrm{min}^{-1}$ ( $\mathrm{mg}$ protein $)^{-1}$. All values are means of three independent experiments. In no case was the variation higher than $15 \%$.

\begin{tabular}{|c|c|c|c|c|c|c|c|c|}
\hline \multirow[t]{3}{*}{ Enzyme } & \multicolumn{8}{|c|}{ Strain } \\
\hline & \multicolumn{2}{|c|}{ dgr139 } & \multicolumn{2}{|c|}{ dgr148 } & \multicolumn{2}{|c|}{$\operatorname{dgr} 1 s 1$} & \multicolumn{2}{|c|}{ dgr239 } \\
\hline & $\begin{array}{c}\text { No } \\
\text { glucose }\end{array}$ & Glucose & $\begin{array}{c}\text { No } \\
\text { glucose }\end{array}$ & Glucose & $\begin{array}{c}\text { No } \\
\text { glucose }\end{array}$ & Glucose & $\begin{array}{c}\text { No } \\
\text { glucose }\end{array}$ & Glucose \\
\hline Maltase & 140 & 101 & 90 & 43 & 135 & 102 & 63 & 44 \\
\hline Invertase & 200 & 120 & 145 & 179 & 210 & 132 & 215 & 220 \\
\hline NAD-GDH & 1985 & 863 & 2100 & 715 & 2025 & 890 & 1223 & 530 \\
\hline$\beta$-Galactosidase & 818 & 810 & 675 & 641 & 856 & 838 & 1158 & 1050 \\
\hline $\mathrm{MDH}$ & 1712 & 1854 & 1850 & 1703 & 1685 & 1670 & 1192 & 1050 \\
\hline
\end{tabular}

600 of these 2-deoxyglucose-resistant $\left(\mathrm{Dgr}^{+}\right)$colonies, retested for their resistance to the analogue, 296 clones that stably maintained the resistant phenotype were analysed further.

In K. lactis, $\mathrm{Rag}^{-}$mutants are unable to grow on glucose when respiration is blocked by specific inhibitors (Goffrini et al., 1989). It was shown previously that mutants in $K$. lactis which have a block in glycolysis are all $\mathrm{Rag}^{-}$ (Goffrini et al., 1990, 1991; Wésolowski-Louvel et al., 1988, 1992a, b; Prior et al., 1993; Heinisch et al., 1993). In order to identify genes involved in glucose metabolism that also controlled carbon catabolite repression, we analysed all the $\mathrm{Dgr}^{+}$mutants for the $\mathrm{Rag}^{-}$phenotype. Among $296 \mathrm{Dgr}^{+}$mutants 184 were $\mathrm{Rag}^{+}$whereas 112 were $\mathrm{Rag}^{-}$.

Since rag1 mutants, affected in the low affinity glucose transport (Goffrini et al., 1990; Wésolowski-Louvel et al., 1992a), display both the $\mathrm{Rag}^{-}$and the $\mathrm{Dgr}^{+}$phenotype (P. Goffrini, unpublished data), all the $\mathrm{Dgr}^{+} \mathrm{Rag}^{-}$mutants isolated were tested for complementation to the rag1 mutant. Among $112 \mathrm{Dgr}^{+} \mathrm{Rag}^{-}$mutants analysed, 107 were found to be allelic to rag1. These mutants will be the subject of another report. The remaining five mutants were analysed further.

\section{Genetic analysis}

Crosses of the five mutants (JA6/138, JA6/139, JA6/148, JA6/151, JA6/239) with a wild-type (PG9-11D) indicate dominance for the $\mathrm{Dgr}^{+}$phenotype and recessiveness for $\mathrm{Rag}^{-}$. The above diploids were subjected to tetrad analysis. In all cases a 2:2 segregation for both phenotypes was observed showing that the mutation is monogenic.

Complementation tests between the different mutants indicate that JA6/138 and JA6/139 are allelic and that JA6/151 could also belong to the same complementation group. JA6/148 and JA6/239 define different genes. The wild-type genes identified by these mutations will be called DGR139, DGR148, DGR151 and DGR239. Complementation tests with other $\mathrm{Rag}^{-}$mutants described (Wésolowski-Louvel et al., 1992b) show that dgr151 is allelic to the rag 5 mutant (mutant in the unique hexokinase structural gene of $K$. lactis; Prior et al., 1993). The possibility of nonlinked noncomplementors has been discarded because a $4^{-}: 0^{+}$segregation was observed in 20 tetrads. The dgr139, dgr 148, dgr239 mutants were not allelic to any of the previously described $\mathrm{Rag}^{-}$mutants. However, further analysis (see Table 5) showed that dgr139 was allelic to rag5.

\section{Biochemical characterization}

To establish whether the mutations that conferred the $\mathrm{Dgr}^{+}$phenotype on raffinose also conferred resistance to the analogue on other carbon sources, the ability of the JA6/139, JA6/148, JA6/151 and JA6/239 mutants to grow on lactose, galactose, maltose and sucrose in the presence of 2-deoxyglucose was compared to that of the wild-type. The resistant phenotype was observed also in the presence of the sugars mentioned above, indicating that the mutations had a pleiotropic effect. The wild-type strain was unable to grow under the same culture conditions. Therefore, we expected that these mutations released the enzymes involved in their utilization from glucose repression. We then assayed the levels of invertase, maltase and $\beta$-galactosidase activities in the newly isolated mutants under repressing and nonrepressing conditions. As shown in Table 4, these enzyme activities were derepressed in all the four mutants. With respect to other catabolite repressible enzymes, not directly related to the utilization of the mentioned sugars, MDH was nonrepressible in the four mutants analysed, whereas NAD-GDH activity was still repressed. L-LCR was not 
Table 5. Hexokinase activity in different strains of K. lactis

Cultures were grown in YP medium supplemented with $2 \%$ $(\mathrm{w} / \mathrm{v})$ glucose. Enzyme activity was measured as described in Methods. Enzyme units are expressed as nmol substrate $\mathrm{min}^{-1}$ $(\mathrm{mg} \text { protein })^{-1}$. All values are means of three independent experiments. In no case was the variation higher than $15 \%$.

\begin{tabular}{|c|c|c|}
\hline Strain & $\begin{array}{l}\text { Relevant } \\
\text { genotype }\end{array}$ & $\begin{array}{c}\text { Hexokinase } \\
\text { activity }\end{array}$ \\
\hline JA6 & $R A G 5$ & 436 \\
\hline JA6/151 × PM6-7A/VV41 & $\begin{array}{l}\operatorname{dgr} 151 \mathrm{R} A G 5 \\
D G R 151 \text { rag } 5\end{array}$ & $<10$ \\
\hline $\mathrm{JA6} / 151 \times \mathrm{PG} 139-7 \mathrm{~B}$ & $\begin{array}{l}\operatorname{dgr} 151 \text { DGR } 139 \\
\text { DGR151 } \operatorname{dgr} 139\end{array}$ & 23 \\
\hline JA6/148 × PM6-7A/VV41 & $\begin{array}{l}\operatorname{dgr} 148 \mathrm{R} A G 5 \\
D G R 148 \mathrm{rag} 5\end{array}$ & 205 \\
\hline $\mathrm{JA6} / 148 \times \mathrm{PG} 239-5 \mathrm{~B}$ & $\begin{array}{l}\text { dgr148 DGR239 } \\
\text { DGR } 148 \text { dgr239 }\end{array}$ & 220 \\
\hline $\mathrm{JA6} / 139 \times \mathrm{PG} 239-5 \mathrm{~B}$ & $\begin{array}{l}\operatorname{dgr} 139 \text { DGR } 239 \\
\text { DGR139 dgr239 }\end{array}$ & 330 \\
\hline
\end{tabular}

analysed in the isolated mutants because this enzyme was detectable at a very low level in the parental strain.

All the mutants analysed were able to utilize glucose, fructose, galactose, lactose and lactate both in complete and in minimal medium. However, all of them displayed an increase of the division time only in media containing glucose and fructose (doubling time of approximately $4 \mathrm{~h}$ instead of approximately $3 \mathrm{~h}$ in minimal medium). Therefore we analysed the hexokinase activity of the mutants. Hexokinase activity was less than 10 enzyme units both in $\mathrm{JA6} / 151$ and in JA6/139, JA6/148 and JA6/239 (data not shown). This result was unexpected since the last three mutants complemented each other and they all complemented the hexokinase mutant rag5.

The results obtained prompted us to measure the hexokinase level in the diploids. The data, reported in Table 5, confirm that dgr 148 and dgr 239 were not mutations in the structural gene encoding hexokinase since the level of this enzyme was restored in the diploids according to the growth phenotype observed previously. In addition, the hexokinase level in the diploid obtained by crossing dgr148 with dgr 239 confirmed that dgr 148 and dgr 239 were mutations in different genes. The results indicate that dgr139 is a mutation of the hexokinase structural gene because the enzyme level in the diploid, obtained by crossing dgr139 with $\operatorname{dgr} 151$, was greatly lowered with respect to a wild-type strain. However this low level could be responsible for the partial growth of the diploids in media containing antimycin A.

\section{DISCUSSION}

The data reported here demonstrate that several enzymes in $K$. lactis are regulated by catabolite repression. In order to identify genes of glucose metabolism that also controlled catabolite repression, we selected 2-deoxyglucose- resistant mutants that were also $\mathrm{Rag}^{-}$(in which the glucose fermentation becomes dependent on respiration). In this way we identified mutants that fell into four complementation groups. Two of these define genes previously described: $R A G 1$ encoding the low affinity glucose transport system, and $\mathrm{R} A G 5$ the unique structural gene encoding hexokinase (Prior et al., 1993). The remaining two genes (DGR148 and DGR239) are required for glucose repression of the enzymes $\beta$ galactosidase, maltase, invertase and MDH but not NADGDH. Both dgr 148 and dgr239 mutants lack hexokinase activity suggesting that these genes are either positive regulators of expression of hexokinase or negative regulators of some proteins which inactivate hexokinase.

The isolation of mutants deficient in hexokinase activity but not of other glycolysis mutants by the applied screen supports the important role of the first enzyme in glucose metabolism during glucose repression in $K$. lactis. Hexokinase could intervene in glucose repression: first, by controlling the rate of glucose metabolism either by glucose phosphorylation or glucose transport or both, and second, by being itself a regulatory protein that acts directly or indirectly on genes controlled by glucose repression. In other words, the role of hexokinase in glucose repression could rest either on its catalytic activity or on its molecular structure. The fact that the absence of hexokinase does not affect the repression of NAD-GDH indicates that this enzyme is regulated by a catabolic control distinct from the one identified here.

The growth on glucose and fructose in the absence of detectable hexokinase activity of all the mutants here described is difficult to explain. However, the growth of mutants on glucose is abolished when the respiration is inhibited, and the division time of mutants is longer than that of the parental strain in glucose- and in fructose- but not in galactose, lactose- or lactate-containing media. All together, these observations can be explained by a low level of hexokinase (less than 10 enzyme units) that could represent a bottle-neck for the growth on glucose and fructose only.

The mutations here described are recessive for the $\mathrm{Rag}^{-}$ phenotype and dominant for the $\mathrm{Dgr}^{+}$phenotype. This apparent paradox presumably was due to the fact that in the diploid strains the hexokinase activity attains a level sufficient to sustain the cell growth in the absence of respiration ( $\mathrm{Rag}^{+}$phenotype), but not sufficient to render the cells insensitive to 2-deoxyglucose ( $\mathrm{Dgr}^{+}$phenotype). This suggests that the threshold of hexokinase activity necessary for glucose repression is higher than the threshold for the ability to grow on glucose in the absence of respiration.

From this study an important difference between $S$. cerevisiae and $K$. lactis emerges: in S. cerevisiae there are multiple hexokinase-encoding genes with only one of the genes specifically responsible for glucose repression (Entian \& Fröhlich, 1984; Ma \& Botstein, 1986; Walsh et al., 1991), whereas in K. lactis there is a single hexokinase (Prior $e t$ al., 1993), and that appears to be regulated by at least two genetic determinants (DGR 148 and DGR239). 
Results obtained in this study demonstrate that, in $K$. lactis, invertase is induced by the substrate raffinose, in contrast to what occurs in S. cerevisiae, in which invertase is regulated only by glucose repression (Carlson \& Botstein, 1982). However, recent results have shown that in S. cerevisiae maximal expression of invertase actually requires a low concentration of glucose (Vallier \& Carlson, 1991; Flick \& Johnston, 1991). A similar phenomenon could explain the result in $K$. lactis, where a small amount of glucose resulting from hydrolysis of raffinose results in higher levels of invertase than in cells growing on lactate. Maltase, which is regulated in the PM4-4B strain as in S. cerevisiae (Vanoni et al., 1989), i.e. induced by maltose and repressed by glucose, is constitutively present in the JAG strain and is repressed twofold by its own substrate, maltose. This peculiar situation could be due to rapid catabolism of the inducer that causes glucose repression. The repressing effect of the substrate could be observed in this strain only, due to the constitutivity of the enzyme. The genetic basis of this control is under investigation.

\section{ACKNOWLEDGEMENTS}

We are grateful to Jack von Borstel for helpful discussion. We thank Micheline Wésolowski-Louvel, Karin Breunig and Jürgen Heinisch for providing strains. This work was supported by the Commission of the European Communities [BIOT CT 91-0267 (DSCN)] and by the Ministero della Ricerca Scientifica e Tecnologica.

\section{REFERENCES}

Breunig, K. D. (1989). Glucose repression of $L A C$ gene expression in yeast is mediated by the transcriptional activator LAC9. Mol \& Gen Genet 216, 422-427.

Breunig, K. D. \& Kuger, P. (1987). Functional homology between the yeast regulatory proteins GAL4 and LAC9: LAC9-mediated transcriptional activation in Kluyveromyces lactis involves protein binding to a regulatory sequence homologous to the GAL4 proteinbinding site. Mol Cell Biol 7, 4400-4406.

Carlson, M. \& Botstein, D. (1982). Two differentially regulated mRNAs with different $5^{\prime}$ ends encode secreted and intracellular forms of yeast invertase. Cell 28, 145-154.

Celenza, J. L. \& Carlson, M. (1984). Cloning and genetic mapping of $S N F 1$, a gene required for expression of glucose repressible genes in Saccharomyces cerevisiae. Mol Cell Biol 4, 49-53.

Clifton, D., Weinstock, S. B. \& Fraenkel, D. G. (1978). Glycolysis mutants in Saccharomyces cerevisiae. Genetics 88, 1-11.

Cohn, M. \& Monod, J. (1951). Purification et proprieté de la $\beta$ galactosidase d'Escherichia coli. Biochim Biopbys Acta 7, 153-165.

De Deken, R. H. (1966a). The Crabtree effect: a regulatory system in yeast. $J$ Gen Microbiol 44, 149-156.

De Deken, R. H. (1966b). The Crabtree effect and its relation to the petite mutation. J Gen Microbiol 44, 157-165.

Dickson, R. C. \& Markin, J. S. (1980). Physiological studies of $\beta$-galactosidase induction in Kluyveromyces lactis. $J$ Bacteriol 142, 777-785.

Entian, K. D. \& Fröhlich, K. U. (1984). Saccharomyces cerevisiae mutants provide evidence of hexokinase PII as a bifunctional enzyme with catalytic and regulatory domains for triggering carbon catabolite repression. J Bacteriol 158, 29-35.
Ferrero, I., Rossi, C., Landini, M. P. \& Puglisi, P. P. (1978). Role of the mitochondrial protein synthesis in the catabolite repression of the petite-negative yeast Kluyveromyces lactis. Biocbem Biophys Res Commun 80, 340-348.

Flick, J. S. \& Johnston, M. (1991). GRR1 of Saccbaromyces cerevisiae is required for glucose repression and encodes a protein with leucine-rich repeats. Mol Cell Biol 11, 5101-5112.

Gancedo, J. M. (1992). Carbon catabolite repression in yeast. Eur J Biochem 206, 297-313.

Gancedo, J. M. \& Gancedo, C. (1986). Catabolite repression mutants of yeast. FEMS Microbiol Rev 32, 179-187.

Goffrini, P., Algeri, A. A., Donnini, C., Wésolowski-Louvel, M. \& Ferrero, I. (1989). R $A G 1$ and $R A G 2$ : nuclear genes involved in the dependence/independence on mitochondrial respiratory functions for the growth on sugars. Yeast 5, 99-106.

Goffrini, P., Wésolowski-Louvel, M., Ferrero, I. \& Fukuhara, H. (1990). RAG1 gene of the yeast Kluyveromyces lactis codes for a sugar transporter. Nucleic Acids Res 18, 5294.

Goffrini, P., Wésolowski-Louvel, M. \& Ferrero, I. (1991). A phosphoglucose isomerase gene is involved in the Rag phenotype of the yeast Kluyveromyces lactis. Mol \& Gen Genet 228, 401-409.

Goldstein, A. \& Lampen, J. O. (1975). $\beta$-D-Fructofuranoside fructohydrolase from yeast. Methods Enzymol 42, 504-511.

Gorts, C. P. M. (1967). Effect of different carbon sources on the regulation of carbohydrate metabolism in Saccharomyces cerevisiae. Antonie Leeuwenboek 33, 451-456.

Grisolia, S., Quisado, C. L. \& Fernandez, M. (1964). Glutamate dehydrogenase from yeast and from animal tissues. Biochim Biopbys Acta 81, 61-70.

Heinisch, J., Kirchrath, L., Liesen, T., Vogelsang, K. \& Hollenberg, C. P. (1993). Molecular genetics of phosphofructokinase in the yeast Kluyveromyces lactis. Mol Microbiol 8, 559-570.

Lodi, T., O'Connor, D., Goffrini, P. \& Ferrero, I. (1994). Carbon catabolite repression in Kluyveromyces lactis: isolation and characterization of the KIDLD gene encoding the mitochondrial enzyme D-lactate ferricytochrome c oxidoreductase. Mol \& Gen Genet 244, 622-629.

Ma, H. \& Botstein, D. (1986). Effects of null mutations in the hexokinase genes of Saccharomyces cerevisiae on catabolite repression. Mol Cell Biol 6, 4046-4052.

Magasanik, B. (1961). Catabolite repression. Cold Spring Harbor Symp Quant Biol 26, 249-256.

Polakis, E. S. \& Bartley, W. (1965). Changes in the enzyme activities of Saccharomyces cerevisiae during aerobic growth on different carbon sources. Biochem J 97, 284-297.

Polakis, E. S., Bartley, W. \& Meek, G. A. (1965). Changes in the activities of respiratory enzymes during the aerobic growth on different carbon sources. Biochem J 97, 298-304.

Prior, C., Mamessiere, P., Fukuhara, H., Chen, X. J. \& WésolowskiLouvel, M. (1993). The hexokinase gene is required for transcriptional regulation of the glucose transporter gene $R A G 1$ in Kluyveromyces lactis. Mol Cell Biol 13, 3882-3889.

Salmeron, J. M. \& Johnston, S. A. (1986). Analysis of the Kluyveromyces lactis positive regulatory gene $L A C 9$ reveals functional homology to, but sequence divergence from, the Saccharomyces cerevisiae GAL4 gene. Nucleic Acids Res 14, 7767-7780.

Slonimski, P. P. (1953). Formation des enzymes respiratoires chez la levure. Paris: Masson et Cie Editeurs.

Vallier, L. G. \& Carlson, M. (1991). New SNF genes, GAL11 and GRR1 affect SUC2 expression in Saccharomyces cerevisiae. Genetics 129, 675-684. 
Vanoni, M., Sollitti, P., Goldenthal, M. \& Marmur, J. (1989). Structure and regulation of the multigene family controlling maltose fermentation in budding yeast. Prog Nucleic Acid Res Mol Biol 37, 281-322.

Walsh, R. B., Clifton, D., Horak, J. \& Fraenkel, D. G. (1991). Saccharomyces cerevisiae null mutants in glucose phosphorylation: metabolism and invertase expression. Genetics 128, 521-527.

Wésolowski, M., Algeri, A. A., Goffrini, P. \& Fukuhara, H. (1982). Killer DNA plasmids of the yeast Kluyveromyces lactis. I. Mutations affecting the killer phenotype. Curr Genet 5, 191-197.

Wésolowski-Louvel, M., Goffrini, P. \& Ferrero, I. (1988). The $\mathrm{R} A G 2$ gene of the yeast Kluyveromyces lactis codes for a putative phosphoglucose isomerase. Nucleic Acids Res 16, 8714.

Wésolowski-Louvel, M., Goffrini, P., Ferrero, I. \& Fukuhara, I. (1992a). Glucose transport in the yeast Kluyveromyces lactis. 1. Properties of an inducible low-affinity glucose transporter gene. Mol \& Gen Genet 233, 89-96.

Wésolowski-Louvel, M., Prior, C., Bornecque, D. \& Fukuhara, H. (1992b). $\mathrm{Rag}^{-}$mutations involved in glucose metabolism in yeast: isolation and genetic characterization. Yeast 8, 711-719.
Wray, L. V., Jr, Witte, M. M., Dickson, R. C. \& Riley, M. I. (1987). Characterization of a positive regulatory gene, $L A C$, that controls induction of the lactose-galactose regulon of Kluyveromyces lactis: structural and functional relationship to GAL4 of Saccharomyces cerevisiae. Mol Cell Biol 7, 1111-1121.

Zachariae, W., Kuger, P. \& Breunig, K. D. (1993). Glucose repression of lactose/galactose metabolism in Kluyveromyces lactis is determined by the concentration of the transcriptional activator LAC9. Nucleic Acids Res 21, 69-77.

Zimmermann, F. K. \& Scheel, I. (1977). Mutants of Saccharomyces cerevisiae resistant to carbon catabolite repression. Mol \& Gen Genet 154, 75-82.

Zimmermann, F. K., Kaufmann, I., Rosenberger, H. \& Hausmann, P. (1977). Genetics of carbon catabolite repression in Saccharomyces cerevisiae: genes involved in the derepression process. Mol \& Gen Genet 151, 95-103.

Received 16 June 1994; revised 17 October 1994; accepted 24 October 1994. 